\title{
RESPONSE OF EGYPTIAN LUPINE (Lupinus termis Forssk.) PLANTS GROWN IN CALCAREOUS SOIL TO ACTIVE DRY YEAST AT DIFFERENT CONCENTRATIONS
}

\author{
Ramadan A. Medani
}

Agric. Bot. Dept., Fac. of Agric., Fayoum University, Fayoum, Egypt.

\begin{abstract}
Two pots experiments were carried out during two successive seasons of 2003/2004 and 2004/2005 at Faculty of Agriculture, Fayoum University to study the response of Egyptian lupine plant cv. Giza 2 grown in calcareous soil to foliar application with active dry yeast at different concentrations. Plants were sprayed three times with yeast concentrations of $0,0.1,0.2,0.3,0.4,0.5,0.6,0.7$ and $0.8 \%$. The obtained results during the two studied seasons revealed that, growth characters of Egyptian lupine plant cv. Giza 2, i.e., plant height, root length, number of leaves /plant, leaf area, number of branches /plant and fresh as well as dry weights were significantly increased at active dry yeast concentrations over $0.1 \%$ comparing to those of unsprayed plants. The maximum growth values were attained at concentrations of $0.5 \%$. Yield and most its components represented by peduncle length, number of pods, number of seeds, weight of pods, weight of seeds and seeds yield/plant as well as weight of 100 -seeds were also increased at active dry yeast concentrations higher than $0.1 \%$. However the enhancement growth characters due to yeast application was more observed from anatomical studies. Where sections diameters of roots, stems and leaf petiole were increased, resulting from increasing phelloderm thickness and diameter of vascular cylinder for root; average cortical cell diameter, thickness of vascular cylinder for stem and vascular bundle dimensions for leaf petiole. Also medvein and blade thickness were increased in plants sprayed with yeast especially at concentrations higher than $0.5 \%$. Such increases resulted from increasing palisade and spongy tissues thickness and vascular bundle dimensions. Yeast application had stimulatory effect on N.P.K, chlorophyll a, b and carotenoids concentrations in Egyptian lupine leaves and total carbohydrates, total $\mathrm{N}$, protein and total alkaloids in dry seeds.
\end{abstract}

Key words: Biofertilizers, active dry yeast, Egyptian lupine, Fabaceae.

\section{INTRODUCTION}

Nowadays, great attention has been focused on the possibility of using natural and safety substances to get lower pollution and enhancing growth and productivity of the plants. The application of active dry yeast as natural stimulator to improve growth and yield is getting much importance. Yeast (as natural stimulator) is characterized by its high protein content, its vitamin B content, thiamin, riboflavin and pyridoxines. Also, yeast is prolific procedures vitamins, amino acids, hormones and other growth substances (Mounolau, 1971; Eid, 1977 and Hegab et al., 1997). In addition, active dry yeast releases $\mathrm{CO}_{2}$ which reflects in improving net photosynthesis (Ferguson

Fayoum J. Agric. Res. \& Dev., Vol. 20, No. 2, July, 2006 
et al., 1987 and Idso et al., 1995). The beneficial effect of yeast was reported by the results obtained by Fathy and Farid, (1996); Ahmed, (1998); ElDesouky et al., (1998) Ahmed and Ali, (2001); Naguib and khalil, (2002); Wanas, (2002); Wahba, (2002) and El-Emery, (2004) on many plants species. Egyptian lupine plant is one of the most important legumes in the world, belongs to Fabaceae family. It has been used as a green manure, forage and seeds for human consumption because its high protein content, but the literature with respect to it and /or Fabaceae plants was rare. The main purpose of this investigation was to study the possibility of using active dry yeast as natural stimulating substance in order to improve growth, yield, anatomical characters and some chemical constituents of Egyptian lupine (Lupinus termis Forssk.) plant.

\section{MATERIALS AND METHODS}

This work was carried out at the Faculty of Agriculture, Fayoum University during two successive seasons of 2003/2004 and 2004/2005.Seeds of Egyptian lupine plant, cv., Giza 2 were secured from Agronomy Department, Faculty of Agriculture, Fayoum University. Seeds were sown on November $16^{\text {th }}$ at the two successive seasons in clay pots $(50 \mathrm{~cm}$ in diameter), each was filled with $12 \mathrm{~kg}$ calcareous soil. Chemical analysis of the soil used was carried out by Soil and Plant analysis Lab., Faculty of Agriculture, Fayoum University (Table, 1).

Table (1): Soil chemical analysis of the soil used.

\begin{tabular}{|l|l|l|l|l|l|l|l|l|}
\hline Soil type & $\mathrm{PH}$ & \multicolumn{6}{|c|}{ Concentrations (mequ /l in soil paste } \\
\hline \multirow{3}{*}{ Calcareous } & & \multicolumn{5}{|c|}{ Cations } & \multicolumn{3}{c|}{ Anions } \\
\cline { 2 - 9 } & & $\mathrm{Ca}^{++}$ & $\mathrm{Mg}^{++}$ & $\mathrm{Na}^{+}$ & $\mathrm{K}^{+}$ & $\mathrm{Cl}^{--}$ & $\mathrm{HCO}_{3}^{--}$ & $\mathrm{SO}_{4}^{--}$ \\
\cline { 2 - 9 } & 8.50 & 67.3 & 59.0 & 70.60 & 2.33 & 140.8 & 2.50 & 120.99 \\
\hline
\end{tabular}

Five seeds were sown in each pot and were thinned to three plants after complete germination (21days old plants). Irrigation and fertilization as well as other cultural practice were done as recommended by Ministry of Agriculture for Egyptian lupine plant. The active dry yeast (Saccharomyces cerevisiae) powder was obtained from Microbial Res. Dept., Agric. Res. Center, Giza). The dry yeast was activated by using sources of carbon and nitrogen at the ratio 6:1 (Barnett $\boldsymbol{e t}$ al., 1990). This ratio is suitable for the highest vegetative reproduction of yeast (each $1 \mathrm{ml}$ yeast contained about 12000 yeast cells). The media was frozen and thawed directly before usage. Plants were sprayed with active dry yeast solution at the concentrations of 0 , $0.1,0.2,0.3,0.4,0.5,0.6,0.7$ and $0.8 \%$ three times at 20 days intervals starting from one month old. Plants were sprayed in the morning until dripping using Tween 20 as surfactant at the rate of $1 \mathrm{ml} / 1$.. Control plants were sprayed with distilled water in addition to the surfactant .The experiment was designed in a complete randomized block design with nine treatments and three replicates, each replicate was represented by 5 pots. At the age of three months in the two seasons the following data were recorded:-

A- Growth parameters

1- Plant height $(\mathrm{cm})$ was measured from the cotyledonary node to the terminal bud.

2- Root length $(\mathrm{cm})$ was measured from the cotyledonary node to the root apex.

Fayoum J. Agric. Res. \& Dev., Vol. 20, No. 2, July, 2006 
RESPONSE OF EGYPTIAN LUPINE (Lupinus termis Forssk.)..... 143

3- Number of leaves /plant.

4-Leaf area $(\mathrm{cm} 2)$ : Leaf area of full expanded leaf $\left(10^{\text {th }}\right.$ leaf $)$ was determined by LI -Core Area Meter, Model LI 3000.

5-Number of branches /plant

6-Fresh weight /plant.

7-Dry weight /plant. For dry weight estimation, plants were dried in an oven at $70 \mathrm{C}^{\circ}$ until its constant weight then the dry weight was recorded.

B-Yield and its components parameters:- At the harvest the data were recorded as follows:-

1-Peduncle length $(\mathrm{cm})$. 2- Number of pods /plant.

3-Number of seeds/pod. 4- Weight of pods /plant (g).

5- Weight of seeds /plant (g). 6- Weight of 100-seeds(g).

C-Anatomical study:- Samples for anatomical study were taken during the second season at the age of three months. Specimens from the root, the middle part of the $10^{\text {th }}$ internode and its leaf (terminal leaflet) including leaf petiole were killed and fixed in F.A.A. solution $(10 \mathrm{ml}$ formalin $+5 \mathrm{ml}$ glacial acetic acid $+35 \mathrm{ml}$ distilled water $+50 \mathrm{ml}$ ethyl alcohol $95 \%$ ) for 48 hours. Thereafter, samples were washed in $50 \%$ ethyl alcohol solution, dehydrated and cleared in n-butyl alcohol series, embedded in paraffin wax of 56-58 m.p. $\mathrm{C}^{\mathrm{o}}$. Cross sections $15 \mathrm{u}$ thick were cut using a rotary microtome, adhesived with Haupt,s adhesive and stained with crystal violet-erythrosin combination (Sass, 1961), cleared in carbol xylene and mounted in Canada balsam. Measurements were done using a micrometer eyepiece and average of 5 readings were calculated.

\section{D-Chemical analysis :-}

Samples of fresh leaves were taken and chlorophyll $a, b$ and carotenoids were extracted and determined $(\mathrm{mg} / 100 \mathrm{~g})$ according to the method described by Fadeel, (1962). Samples of leaves and seeds (dried in an oven at $70^{\circ} \mathrm{C}$ till constant weight) were taken then ground for determination of total $\mathrm{N}$ (in leaves and seeds) calorimetrically by using Orange $G$ dye according to the method described by Hafez and Hikkelsen, (1981). Phosphorus in leaves digested solution was calorimetrically determined according to Jackson, (1967). Potassium in digested solution leaves was determined according to Brown and Lilliand (1966) by Flame Photometer, Perkin-Elmer Model 52 with acetylene burner. Total carbohydrates $\%$ in seeds were determined calorimetrically according to the methods described by Dubois et al., (1965). Crude protein was calculated by multiple total $\mathrm{N} \%$ x 6.25 . Total alkaloids $\%$ in seeds were determined according to Atta et al., (1985). All data were statistically analyzed according to Snedecor and Cochran, (1982).

\section{RESULTS AND DISCUSSION}

\section{Vegetative growth characters}

Data presented in Table (2) show that spraying active dry yeast was very effective in improving growth parameters represented by plant height, root length, number of leaves /plant, leaf area, number of branches/ plant and fresh as well as dry weights of Egyptian lupine plants during the two studied seasons. Where all growth parameters mentioned above were significantly increased by increasing active dry yeast concentrations. Moreover, the maximum values for most studied growth parameters were recorded by plants sprayed with $0.5 \%$ active dry yeast concentration in comparison to the untreated ones. The superior effect of yeast on vegetative growth of Egyptian lupine plants in this work might be attributed to that yeast application

Fayoum J. Agric. Res. \& Dev., Vol. 20, No. 2, July, 2006 
Table 2

Fayoum J. Agric. Res. \& Dev., Vol. 20, No. 2, July, 2006 
RESPONSE OF EGYPTIAN LUPINE (Lupinus termis Forssk.)..... 145 increased N,P,K and photosynthetic pigments in the leaves, those which known to be closely related with the efficiency of photo assimilation, carbohydrate and protein synthesis, involved in growth activities. In addition, yeast suggested to play of growth stimulatory role via their cytokinins function (Jameson, 1994 and Fathy et al., 2000). Also, the promotional effect of yeast treatments on Egyptian lupine plant growth could be due to its content of auxins, GA, cytokinnis, carbohydrate, protein and mineral contents. Thus it might accelerate cell division and enlargement and all metabolic processes, (Roberts, 1976 and Karaig and Haber, 1980). The best results were observed by using active dry yeast until the concentration of $0.5 \%$ comparing to the control, but the high concentrations over it did not show more responses. The significant increase in plant growth characters observed after the application of yeast as mentioned previously are in full agreement with those achieved by Ahmed et al., (1998); El-Desouky et al., (1998); Fathy and Farid, (2000); Naguib and Khalil, (2002); Wahba, (2002); El-Emery (2004) and Somida et al., (2005).

\section{Yield and its components}

Data in Table (3) show that, active dry yeast application had a stimulating effect on yield and its components of Egyptian lupine plants. During the two studied seasons most yield parameters were significantly increased at active dry yeast concentration higher than $0.1 \%$, only weight of 100 - seeds was significantly increased by active dry yeast application over $0.2 \%$ comparing to the control. All yield parameter values reached to their maximum at $0.5 \%$ active dry yeast concentration. Moreover the highest increase was shown in number of seeds/ plant (84.4 and 107.4) followed by number of pods/plant (77.8 and $105.7 \%$ ) comparing to the control at the first and second seasons respectively. It is clear from the present study that improving seeds yield of Egyptian lupine plants might be due to the resultant increase in number of pods, and number of seeds/ plant as well as weight of 100- seeds might be closely related to the beneficial role of yeast during vegetative and reproductive growth through improving flower formation and their set of plants due to its greater content of mineral and certain natural hormones (auxins and cytokinnis (Roberts, 1976 and Barnett et al., 1990). In addition, the increase in the release of carbon dioxide through fermentation processes effectively stimulates photosynthesis and accelerates the biosynthesis of carbohydrates. Similar results were obtained by Atawia and El- Desouky (1997), El-Mogy et al., (1998); Abd El-Kafie et al. (2001); Naguib and Khalil (2002) and Wanas (2002).

\section{Anatomical studies:}

\subsection{Root:}

Table (4) and Fig. (1) show that, active dry yeast application had a stimulating effect on the root tissues of Egyptian lupine plant, where all root tissues measurements were increased at all yeast concentrations used in the study in comparison to the control except the average diameter of secondary xylem vessels which fluctuated.The highest active dry yeast concentration $(0.8 \%)$ resulted in the highest increase in section diameter $(82.2 \%)$ and vascular cylinder diameter $(102.0 \%)$ in comparison to those of the control. Also, the highest increase in phelloderm thickness $(206.1 \%)$ and its layers number $(34.14 \%)$ were observed at $0.4 \%$ active dry yeast concentration comparing to those of the control. Average diameter of secondary xylem vessels was also increased by $18.33 \%$ over the control at $0.5 \%$ yeast concentration.

Fayoum J. Agric. Res. \& Dev., Vol. 20, No. 2, July, 2006 
Table 3

Fayoum J. Agric. Res. \& Dev., Vol. 20, No. 2, July, 2006 
RESPONSE OF EGYPTIAN LUPINE (Lupinus termis Forssk.)..... 147

Fig. 1

Fayoum J. Agric. Res. \& Dev., Vol. 20, No. 2, July, 2006 
Ramadan A. Medani

Table (4): Root tissues of Egyptian lupine terms plant grown in calcareous soil as affected by active dry yeast at different concentrations.

\begin{tabular}{|c|c|c|c|c|c|}
\hline \multirow{2}{*}{$\begin{array}{l}\text { Characters } \\
\\
\text { Yeast solution } \\
\text { concentration }\end{array}$} & \multirow[b]{2}{*}{ 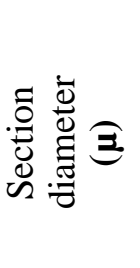 } & \multicolumn{2}{|c|}{ Phelloderm } & \multirow[b]{2}{*}{ 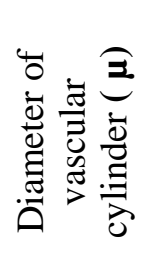 } & \multirow{2}{*}{ 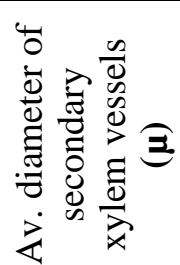 } \\
\hline & & 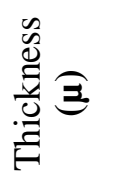 & 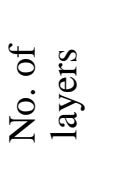 & & \\
\hline Control & 1917.0 & 213.0 & 8.20 & 1363.0 & 60.00 \\
\hline $0.1 \%$ & 2308.0 & 216.0 & 9.50 & 1836.0 & 48.00 \\
\hline $0.2 \%$ & 2605.0 & 488.0 & 9.30 & 1701.0 & 54.00 \\
\hline $0.3 \%$ & 2565.0 & 460.0 & 9.40 & 1809.0 & 55.00 \\
\hline $0.4 \%$ & 2997.0 & 652.0 & 11.00 & 2187.0 & 45.00 \\
\hline $0.5 \%$ & 2848.0 & 370.0 & 11.40 & 1998.0 & 71.00 \\
\hline $0.6 \%$ & 2794.0 & 428.0 & 8.40 & 2241.0 & 61.00 \\
\hline $0.7 \%$ & 3429.0 & 417.0 & 10.20 & 2565.0 & 65.00 \\
\hline $0.8 \%$ & 3591.0 & 631.0 & 9.30 & 2754.0 & 58.00 \\
\hline
\end{tabular}

\section{2. Stem:-}

Data presented in Table (5) and Fig. (2) reveal that, stem section diameter was increased at most yeast concentrations used except at $0.1 \%$, where it was decreased, such increase reached to its maximum (35.3\%) at the highest yeast concentration $(0.8 \%)$ in comparison to the control. Moreover, at all yeast concentrations used, the increase in the stem section diameter resulted from increasing average cortex cell diameter, thickness of vascular cylinder average diameter of secondary xylem vessels and pith thickness as well as its layers number. The highest increase $(117.35 \%)$ was noticed in average cortex cell diameter at active dry yeast concentration of $0.2 \%$ comparing to the control.

Table (5): Stem tissues of Egyptian lupine plant grown in calcareous soil as affected by active dry yeast at different concentrations.

\begin{tabular}{|c|c|c|c|c|c|c|}
\hline \multirow{2}{*}{$\begin{array}{l}\text { Characters } \\
\text { Yeast solution conc. }\end{array}$} & \multirow[b]{2}{*}{ 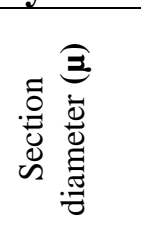 } & \multirow[b]{2}{*}{ 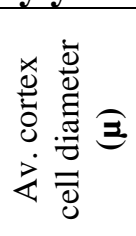 } & \multirow[b]{2}{*}{ 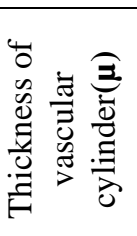 } & \multirow[b]{2}{*}{ 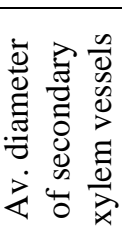 } & \multicolumn{2}{|c|}{ Pith } \\
\hline & & & & & 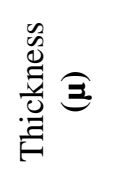 & $\begin{array}{l}\tilde{0} \\
\dot{0} \\
\dot{0} \\
\dot{\vec{\omega}}\end{array}$ \\
\hline Control & 4729.0 & 20.52 & 663.0 & 41.0 & 3105.0 & 27.0 \\
\hline $0.1 \%$ & 4538.0 & 41.26 & 471.0 & 42.0 & 3294.0 & 38.0 \\
\hline $0.2 \%$ & 6021.0 & 44.60 & 986.0 & 53.0 & 3591.0 & 32.0 \\
\hline $0.3 \%$ & 5454.0 & 23.21 & 560.0 & 61.0 & 3240.0 & 34.0 \\
\hline $0.4 \%$ & 5481.0 & 15.60 & 541.0 & 48.0 & 4266.0 & 29.0 \\
\hline $0.5 \%$ & 5940.0 & 28.00 & 613.0 & 53.0 & 3510.0 & 30.0 \\
\hline $0.6 \%$ & 6376.0 & 27.20 & 639.0 & 46.0 & 3834.0 & 48.0 \\
\hline $0.7 \%$ & 5348.0 & 29.70 & 680.0 & 53.0 & 3781.0 & 48.5 \\
\hline $0.8 \%$ & 6399.0 & 30.40 & 693.0 & 54.0 & 4185.0 & 62.0 \\
\hline
\end{tabular}

Fayoum J. Agric. Res. \& Dev., Vol. 20, No. 2, July, 2006 
RESPONSE OF EGYPTIAN LUPINE (Lupinus termis Forssk.)..... 149

Fig. 2

Fayoum J. Agric. Res. \& Dev., Vol. 20, No. 2, July, 2006 
3.3. Leaf petiole:-

Table (6) and Fig.(3) clear that all leaf petiole tissues i.e., section diameter, number and dimensions of vascular bundles and average of xylem vessel diameter were increased in plants sprayed with active dry yeast comparing to those of unsprayed ones. Most increase of section diameter resulted from increasing vascular bundle dimensions and hollow pith diameter, where number of vascular bundles was slightly increased.

\subsection{Leaf blade:-}

Midvein and leaf blade thickness of Egyptian lupine were increased at all yeast concentrations used as shown in Table (7) and Fig.(4). The only exception was the reduction in blade thickness which observed at $0.4 \%$ active dry yeast concentration. The increase in both midvein and blade thickness accompanied with increasing palisade tissues thickness, vascular bundles dimensions and number and diameter of xylem vessels. In this concern, the best results were noticed at the concentrations of 0.5 and $0.6 \%$ active dry yeast except spongy tissue thickness which was slightly decreased by $(-6.6 \%)$ at concentration of $0.5 \%$ comparing to the control. The maximum increase was $301.3 \%$ over the control in vascular bundle length at $0.6 \%$ yeast concentration. Also palisade and spongy tissues were increased by 58.7 and $9.9 \%$ respectively at the same concentration comparing to the control. It is clear from the mentioned previously results that yeast application was positively affected on all Egyptian lupine plant tissues. This might be attributed to the effect of yeast on increasing levels of endogenous hormones in treated plants which could be due to cell division and enlargement. Similar results were obtained by Wanas et al., (1998) and Wanas, (2002).

Table (6): Leaf petiole tissues of Egyptian lupine plant grown in calcareous soil as affected by active dry yeast at different concentrations.

\begin{tabular}{|c|c|c|c|c|c|c|}
\hline $\begin{array}{l}\text { Characters } \\
\text { Yeast solution conc. }\end{array}$ & 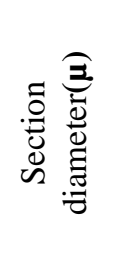 & 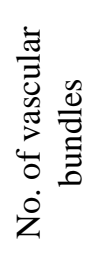 & 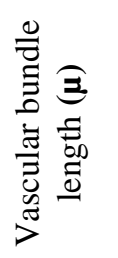 & 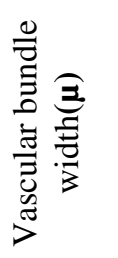 & 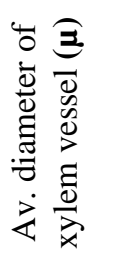 & 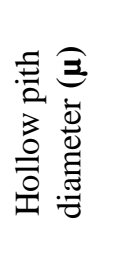 \\
\hline Control & 1485.0 & 7.0 & 302.0 & 452.0 & 25.0 & 382.0 \\
\hline $0.1 \%$ & 1512.0 & 7.0 & 315.0 & 470.0 & 30.0 & 410.0 \\
\hline $0.2 \%$ & 1728.0 & 7.0 & 376.0 & 523.0 & 31.0 & 363.0 \\
\hline $0.3 \%$ & 1782.0 & 8.0 & 362.0 & 514.0 & 31.0 & 534.0 \\
\hline $0.4 \%$ & 1755.0 & 9.0 & 330.0 & 435.0 & 32.0 & 723.0 \\
\hline $0.5 \%$ & 1674.0 & 8.0 & 354.0 & 470.0 & 18.0 & 556.0 \\
\hline $0.6 \%$ & 1919.0 & 8.0 & 365.0 & 461.0 & 29.0 & 730.0 \\
\hline $0.7 \%$ & 1917.0 & 9.0 & 369.0 & 463.0 & 31.0 & 695.0 \\
\hline $0.8 \%$ & 1863.0 & 9.0 & 347.0 & 492.0 & 26.0 & 652.0 \\
\hline
\end{tabular}

Fayoum J. Agric. Res. \& Dev., Vol. 20, No. 2, July, 2006 
RESPONSE OF EGYPTIAN LUPINE (Lupinus termis Forssk.)..... 151

Fig. 3

Fayoum J. Agric. Res. \& Dev., Vol. 20, No. 2, July, 2006 
Fig. 4

Fayoum J. Agric. Res. \& Dev., Vol. 20, No. 2, July, 2006 
RESPONSE OF EGYPTIAN LUPINE (Lupinus termis Forssk.)..... 153

Table (7): Leaf blade tissues of Egyptian lupine plant grown in calcareous soil as affected by active dry yeast at different concentrations.

\begin{tabular}{|c|c|c|c|c|c|c|c|c|}
\hline $\begin{array}{c}\text { Characters } \\
\text { Yeast } \\
\text { solution } \\
\text { conc. }\end{array}$ & 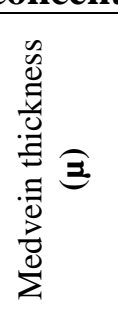 & 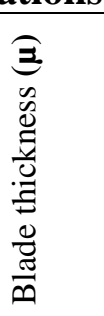 & 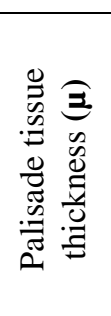 & 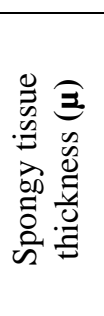 & 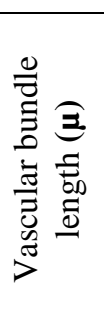 & 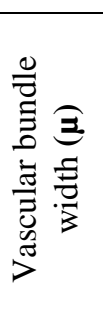 & 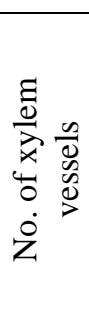 & 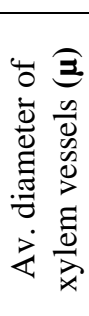 \\
\hline Control & 316.0 & 240.0 & 92.00 & 91.0 & 83.0 & 80.0 & 10.0 & 12.0 \\
\hline $0.1 \%$ & 431.0 & 250.0 & 93.00 & 80.0 & 135.0 & 251.0 & 45.0 & 15.0 \\
\hline $0.2 \%$ & 392.0 & 254.0 & 120.0 & 83.0 & 96.0 & 114.0 & 15.0 & 10.0 \\
\hline $0.3 \%$ & 388.0 & 262.0 & 134.0 & 64.0 & 146.0 & 169.0 & 23.0 & 21.0 \\
\hline $0.4 \%$ & 412.0 & 194.0 & 105.0 & 76.0 & 114.0 & 135.0 & 18.0 & 28.0 \\
\hline $0.5 \%$ & 576.0 & 286.0 & 132.0 & 85.0 & 182.0 & 246.0 & 45.0 & 21.0 \\
\hline $0.6 \%$ & 560.0 & 286.0 & 146.0 & 100.0 & 152.0 & 312.0 & 28.0 & 15.0 \\
\hline $0.7 \%$ & 381.0 & 184.0 & 98.0 & 65.0 & 124.0 & 178.0 & 19.0 & 23.0 \\
\hline $0.8 \%$ & 464.0 & 213.0 & 114.0 & 82.0 & 127.0 & 246.0 & 39.0 & 19.0 \\
\hline
\end{tabular}

\section{Chemical constituents}

\subsection{Chemical constituents of leaves :-}

Data recorded in Table (8) show that, during the two studied seasons, active dry yeast application improved chemical constituents in the leaves. Generally, all chemical constituents studied were significantly increased with active dry yeast over $0.1 \%$ concentrations except $\mathrm{K}$ concentration which significantly increased only at $0.6 \%$ yeast concentration by 10.65 and $4.28 \%$ over control at the first and second seasons, respectively. During the two studied seasons, the best results with respect to $\mathrm{N}$ and $\mathrm{P} \%$ were attained at active dry yeast concentrations ranged from $0.5-0.7 \%$. The highest increase (30.2\%) was shown in $\mathrm{N} \%$ at the first season for plants sprayed with $0.5 \%$ yeast concentration in comparison to that of untreated plants. Concerning with photosynthetic pigments i.e., chlorophyll a, b and carotenoids, the concentration of $0.7 \%$ active dry yeast was the best, at which the increments were 26.3 and $31.2 \%$ for chlorophyll a; 36.11 and $33.6 \%$ for chlorophyll $b$ as well as 11.8 and $17.6 \%$ for carotenoids in comparison to the control at the first and second seasons, respectively (Table, 8). All photosynthetic pigments concentrations were declined at $0.8 \%$ yeast concentration in relation to the concentration below it only but increased relative to the control.

It was observed from the obtained results concerned with chemical constituents of the leaves that, the highest chlorophyll concentration due to yeast treatments was correlated with the nutrient concentrations especially $\mathrm{N}$, this was logically true, since that $\mathrm{N}$ known to be a main component of chlorophyll molecule (Kato and Shimizu, 1985). The positive effect of yeast treatments on photosynthetic pigments could be attributed to higher content of cytokinins, since cytokinins has been reported to enhance the conversion of protoplastids in to chloroplasts (Kulavea, 1979). Also yeast contains higher concentrations of $\mathrm{N}, \mathrm{P}$ and $\mathrm{K}$ and those consequently were increased in Egyptian lupine leaves due to yeast treatments. Similar findings

Fayoum J. Agric. Res. \& Dev., Vol. 20, No. 2, July, 2006 
Ramadan A. Medani

in this respect were obtained by Abd El-Kafie et al., (2001), El-Ghinbihi and Abd El-Fattah, (2001) and Wanas, (2002).

\subsection{Chemical constituents of seeds :-}

The increase in $\mathrm{N}, \mathrm{P}, \mathrm{K}$ and photosynthetic pigments in the leaves due to active dry yeast application was reflected on seeds chemical constituents (Table, 9). During the two of the study seasons, total nitrogen, protein and alkaloids concentrations in seeds were significantly increased at yeast concentrations higher than $0.2 \%$ active dry yeast, while, total carbohydrate concentrations was significantly increased at concentrations higher than $0.4 \%$ in comparison to the control. The highest increases were noticed for seeds protein concentration (26.7 and 23.3) at concentrations of 0.6 and $0.7 \%$ active dry yeast during the first and second seasons respectively. Total carbohydrates concentration was significantly increased by 21.8 and $22.7 \%$ at the highest concentration $(0.8 \%)$ in comparison to the control during the first and second seasons respectively. Increasing chemical concentrations of Egyptian lupine seeds by yeast application might be due to the stimulatory effects of active dry yeast upon the efficiency of photosynthesis process and more photosynthates being created as well as enhancement of mineral translocation from roots to the leaves and seeds. Similar results were obtained by Fathy and Farid, (1996); Naguib and Khalil, (2002) and Wahba, (2002). Finally it can be concluded that, Egyptian lupine plants were more responded to active dry yeast application especially the concentrations of 0.5 and $0.6 \%$. Higher concentrations of yeast did not show more responses.

Fayoum J. Agric. Res. \& Dev., Vol. 20, No. 2, July, 2006 
RESPONSE OF EGYPTIAN LUPINE (Lupinus termis Forssk.)..... 155

Table 8

Fayoum J. Agric. Res. \& Dev., Vol. 20, No. 2, July, 2006 
Table 9

Fayoum J. Agric. Res. \& Dev., Vol. 20, No. 2, July, 2006 
RESPONSE OF EGYPTIAN LUPINE (Lupinus termis Forssk.)..... 157 REFERENCES

Abd El-Kafie, O.M.; A.M. Hamza; H.H. Abd El-Kader and M.M.Abd El-Aty, (2001): Effect of yeast extract, ATP, Vit.B complex and hydrogel on growth, flowering and offsets proliferation of Chrysanthemum plant. J. Agric. Sc., Mansoura Univ., 26(6): 39173931.

Ahmed, E.T., (1998): Influence of concentration and time of spraying active dry yeast on growth and volatile oil content of Marjoram plants. J. Agric. Sc., Mansoura Univ., 23 (11): 5067-5081.

Ahmed, Sh. K.; E.O. El-Ghawas and A.F.Aly, (1998): Effect of active dry yeast and organic manure on roselle plant. Egypt. J. Agric. Res., 76(3) :1115-1143.

Ahmed, Sh. K. and F.A. Ali, (2001): Effect of salinity treatments and active dry yeast on growth and active ingredients of Ambrosia maritima L. Proc. The Fifth Arabian Horticulture Conference Ismailia Egypt, $1: 217-224$.

Atawia, A.A.R. and S.A. El-Desouky, (1997): Trials for improving fruit set, yield and fruit quality of Washington navel orange by application of some growth regulators and yeast extract as a natural source of phytohormones. Ann. Agric. Sci., Moshtohor, 35(3): 1613-1632

Atta, R.; M. Sohail; H. Cunheng and C. John, (1985): Isolation and structure determination of nigellione. A novel alkaloids from seeds of Nigella sativa. Tetrahedron letters, 26(23): 2759-2762.

Barnett, J.A.; R.W. Payne and D. Yarrow, (1990): Yeasts, Characteristics and Identification. Cambridge. Camb. CBZBR, 40 West $20^{\text {th }}$ St. pp. 999.

Brown, J.D. and O. Lilliand (1966): Rapid determination of potassium and sodium in plant and soil extracts by Flame-Photometry. Proc. Amer. Soc. Hort. Sci., 48, 341-363.

Dubois, M.; F. Smith; K.A. Gillers; J.K. Hamliton and P.A. Robers, (1965): Colorimetric methods for determination of sugar and related substances. Analytical Chems. 28: 53.

Eid, N.H., (1977): Some Studies on the Utilization of Yeast in Human Nutrition . Ph. D., Thesis, Fac. of Agric., Cairo Univ.

El-Desouky, S.A.; A. L. Wanas and Z. M. Khedr, (1998): Utilization of some natural plant extracts (of garlic and yeast) as seed-soaked materials to squash, (Cucurbita pepo L.). 1- Effect on growth ,sex expression and fruit yield and quality. J. Ann. of Agric. Sci., Moshtohor, Zagazig Univ., 35(2): 839-854.

El-Emery, G. A. E. (2004): Effect of growth regulators of yeast autalysate, RNA and adenosine on some seeds during germination. Arab Univ. J. Agric. Sci., Ain Shams Univ., Cairo, 12 (1): 51-67.

El-Ghinbihi, F.H. and M.A. AbdEl-Fattah, (2001): Mitigation of the adverse effects of water stress imposed at different stage of taro(Colocasia esculenta (L.) Schott) plant using several treatments. II The influence of biofertilizer (Halex 2) or yeast extract application on growth, chemical composition and yield of taro plants grown under water stress conditions. Minufiya J. Agric. Res., 26(4): 10051034.

Fayoum J. Agric. Res. \& Dev., Vol. 20, No. 2, July, 2006 
El-Mogy, M.M.; A. H. Omer and A.S. Gasser, (1998): Effect of yeast application and bud fertility, physical, chemical properties, vegetative growth and yield of Thompson seedling grape vine.

J. Agric. Sci., Mansoura Univ., 23(8): 3879-3886.

Fadeel, A.A., (1962): Location and properties of chloroplasts and pigments determination in roots. Physiol. Plant.,15:130-147.

Fathy, El-S. L. and S. Farid, (1996): The possibility of using vitamin Bs and yeast to delay senescence and improve growth and yield of common beans (Phaseolus vulgaris L.). J. Agric. Sc. Mansoura Univ., $22(7): 2361-2367$. yeast preparation and royal jelly on some vegetable crops grown in late summer season to induce their ability towards better thermal tolerance. J. Agric. Sc. Mansoura Univ., 25 (4): 2215-2246.

Fathy, El-S.L.; S. Farid and S.A.El-Desouky, (2000): Induce cold tolerance of outdoor tomatoes during early summer season by using triphosphate (ATP), yeast, other natural and chemical treatments to improve their fruiting and yield. J. Agric. Sc. Mansoura Univ.,25 (1): $377-401$.

Ferguson, J.J.; W.T. Avigne; L.H. Allen and K.E. Koch, (1987): Growth of $\mathrm{CO}_{2}$ enriched sour orange seedlings treated with gibberelic and cytokinins .Proc. Florida State Hort. Soci., 99:37-39.

Hafez, A. and D.S. Hikkelsen, (1981): Colorimetric determination of nitrogen for evaluating the nutritional status of rice. Commnu. Soil Sci. and Plant Analysis, 12(1) : 16-69.

Hegab, M.H.; F.F. Ahmed and A.H. Ali, (1997): Influence of spraying active dry yeast on growth and productivity of valencia orange trees (Citrus sinensis L.). First Scientific Conf., Assiut, Fac. of Agric.

Idso, S.B.; K.E. Idso and J.K. Hoober, (1995): Effect of atmospheric $\mathrm{CO}_{2}$ enrichment and foliar methanol application on net photosynthesis of sour orange trees (Citrus aurantum) leaves. Amer. J. Bot., 82(1) :2630 .

Jackson, M.L., (1967): Soil Chemical Analysis. Prentice -Hall of India Private Limited, New Delhi, p. 326-338.

Jameson, P.E., (1994): Cytokinins Metabolism and Compartmentation. In Cytokinins, Mok, D.W. and Moc., M.C. Eds., CRC Press,Boca Roton, F1 (c.f. Methods of Plant Biochemistry and Molecular Biology. Ed. by Dashek, W.V., p. 134-151.

Kariag, E. and J.E. Haber, (1980): Messenger ribonucleic acid and protein metabolism during sporulation of Saccharomyces cervisiae. J. Bacteriol. , 144 : 1098-1112.

Kato, M. and S. Shimizu,(1985) : Chlorophyll metabolism in higher plants involvement of peroxides in Chlorophyll degradation .Plant and Soil, 26:1291-1301.

Kulavea, O.N., (1979): Cytokinins Action on Enzyme Activities on Plants In: Plant Growth Substances (ed.) F. Skoog. Springer -Verlag. Berlin. Heidelberg. New York. Pp.119-128.

Moore, T.C., (1979): Biochemistry and Physiology of Plant Hormones.p.1185-1190. Springer-Verlag, New York.

Mounolau, J.C., (1971): Properties and Composition of Yeast Nucleic Acid. Ed. by Rose, Anthony and Academic, London, England.

Fayoum J. Agric. Res. \& Dev., Vol. 20, No. 2, July, 2006 
RESPONSE OF EGYPTIAN LUPINE (Lupinus termis Forssk.)..... 159

Naguib, N.Y. and M.Y. Khalil, (2002): Studies on the effect of dry yeast thiamine and biotin on the growth and chemical constituents of black cumin (Nigella sativa L.). Arab Univ. J. Agric. Sci., Ain Shams Univ., Cairo, 10 (3): 919-937.

Roberts, L. W., (1976): Cyto differentiation in Plants, Xylogenesis as a Model system. Combridge Univ. Press, UK.

Sass, J.A., (1961): Botanical Microtechnique. Third. Ed. The Iowa State Univ. Press. Ames. Iowa, USA.

Snedecor, W.C. and W.G. Cochran, (1982): Statistical Methods. $7^{\text {th }}$ Ed. $2^{\text {nd }}$ printing. The Iowa State Univ. Press, Ames., Iowa, USA.

Somida, E.G.; Sawsan A. El-Yazal and M.A. El-Yasal, (2005): Effect of active dry yeast and potassium as foliar spray fertilization on growth and chemical constituents of roselle plant (Hibiscus sabdariffa L.,). Egypt. J. of Appl. Sci., 20 (12B) : 451-470.

Wahba, H.E., (2002): Growth, yield and chemical composition of Oenothra biennis as affected by yeast, biotin and riboflavin foliar application. Arab Univ. J. Agric. Sci., Ain Shams Univ., Cairo,10 (3) : 997-1017.

Wanas, A.L.A.; S.A. El-Desouky and Z.M.A. Khedr, (1998): Utilization of some natural plant extracts (of garlic and yeast) as seed-soaked materials to squash (Cucurbita pepo L.) II-Effect on the histological features and the endogenous hormones. Ann. of Agric. Sci., Moshtohor. 3 (2) : 855-878.

Wanas, A.L.A., (2002): Response of faba bean (Vicia faba L.) plants to seed soaking application with natural yeast and carrot. Ann. of Agric. Sci., Moshtohor, 4(1) : 83-`102.

استجابة نباتات الترمس النامية في تربة جيرية للرش بالخميزة عند تركيزات مختلفة

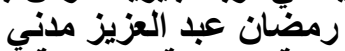

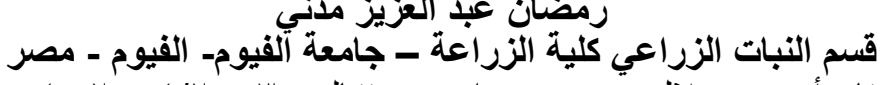

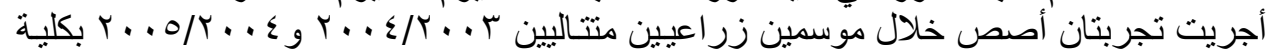

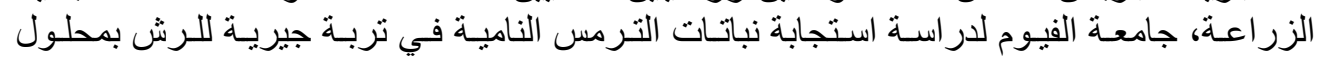

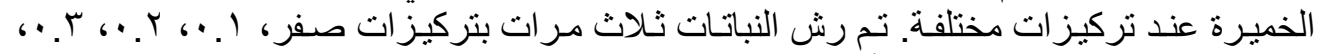

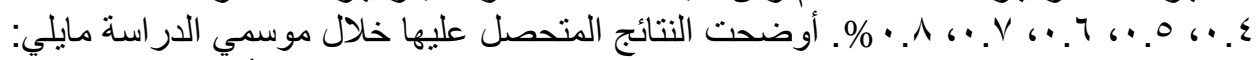

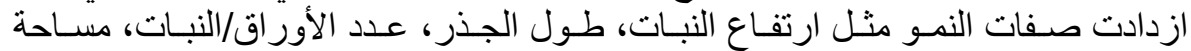

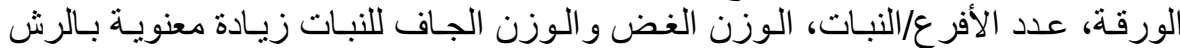

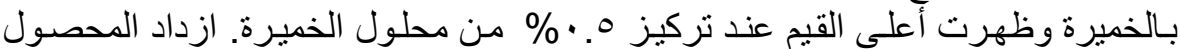

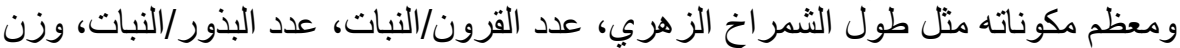

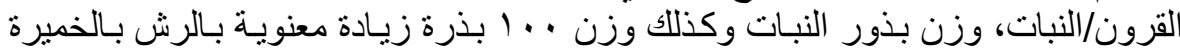

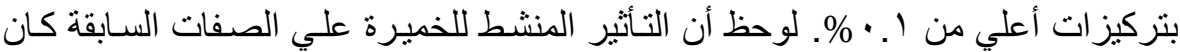

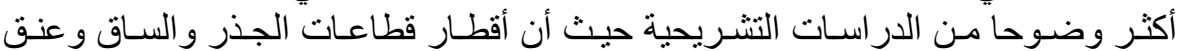

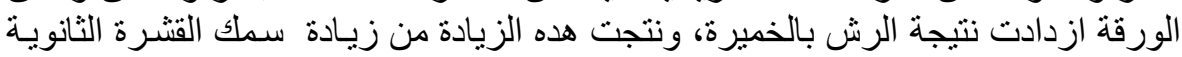

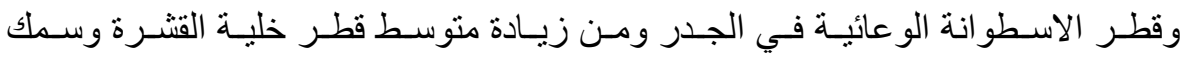

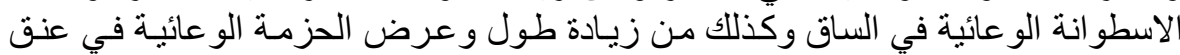

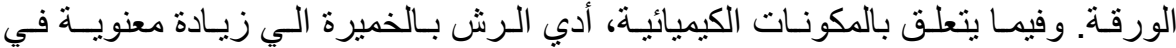

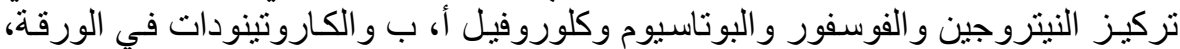

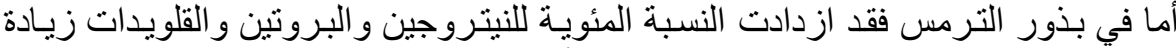

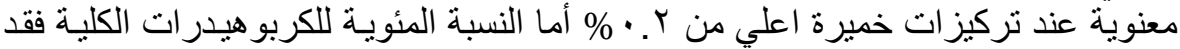

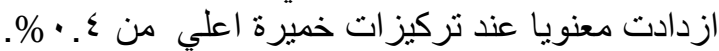

Fayoum J. Agric. Res. \& Dev., Vol. 20, No. 2, July, 2006 
Ramadan A. Medani

$\begin{array}{llllllllll}141 & 142 & 143 & 144 & 145 & 146 & 147 & 148 & 149 & 150\end{array}$

$\begin{array}{llllllllll}151 & 152 & 153 & 154 & 155 & 156 & 157 & 158 & 159 & 160\end{array}$

$\begin{array}{llllllllll}141 & 142 & 143 & 144 & 145 & 146 & 147 & 148 & 149 & 150\end{array}$

$\begin{array}{llllllllll}151 & 152 & 153 & 154 & 155 & 156 & 157 & 158 & 159 & 160\end{array}$

Fayoum J. Agric. Res. \& Dev., Vol. 20, No. 2, July, 2006 